\title{
Repertoire of BALB/c Mice Natural Anti-Carbohydrate Antibodies: Mice vs. Humans Difference, and Otherness of Individual Animals
}

OPEN ACCESS

Edited by:

Victoriano Mulero,

Universidad de Murcia, Spain

Reviewed by:

Peter Isaac Lobo,

University of Virginia,

United States

Harry W. Schroeder,

University of Alabama at Birmingham,

United States

*Correspondence:

Daniel Bello-Gil

dbello@idibell.cat;

Rafael Mañez

rmanez@bellvitgehospital.cat

Specialty section:

This article was submitted to

Comparative Immunology,

a section of the journal

Frontiers in Immunology

Received: 15 June 2017

Accepted: 17 October 2017

Published: 06 November 2017

Citation:

Bello-Gil D, Khasbiullina N, Shilova N, Bovin N and Mañez R (2017) Repertoire of BALB/C Mice Natural

Anti-Carbohydrate Antibodies:

Mice vs. Humans Difference, and Otherness of Individual Animals.

Front. Immunol. 8:1449. doi: 10.3389/fimmu.2017.01449

\author{
Daniel Bello-Gil ${ }^{*}$, Nailya Khasbiullina ${ }^{2}$, Nadezhda Shilova $^{2}$, Nicolai Bovin ${ }^{2}$ \\ and Rafael Mañez ${ }^{1,3 *}$
}

${ }^{1}$ Infectious Pathology and Transplantation Division, Bellvitge Biomedical Research Institute (IDIBELL), Hospitalet de Llobregat, Spain, ${ }^{2}$ Shemyakin-Ovchinnikov Institute of Bioorganic Chemistry, Russian Academy of Sciences, Moscow, Russia, ${ }^{3}$ Intensive Care Department, Bellvitge University Hospital, Hospitalet de Llobregat, Spain

One of the most common genetic backgrounds for mice used as a model to investigate human diseases is the inbred BALB/c strain. This work is aimed to characterize the pattern of natural anti-carbohydrate antibodies present in the serum of $20 \mathrm{BALB} / \mathrm{c}$ mice by printed glycan array technology and to compare their binding specificities with that of human natural anti-carbohydrate antibodies. Natural antibodies (NAbs) from the serum of BALB/c mice interacted with 71 glycans from a library of 419 different carbohydrate structures. However, only seven of these glycans were recognized by the serum of all the animals studied, and other five glycans by at least $80 \%$ of mice. The pattern of the 12 glycans mostly recognized by the circulating antibodies of BALB/c mice differed significantly from that observed with natural anti-carbohydrate antibodies in humans. This lack of identical repertoires of natural anti-carbohydrate antibodies between individual inbred mice, and between mice and humans, should be taken into consideration when mouse models are intended to be used for investigation of NAbs in biomedical research.

Keywords: printed glycan array technology, glycochips, BALB/c, humans, natural antibodies repertoire

\section{INTRODUCTION}

Antibody repertoire has marked the success and perpetuity of species. There is a group of circulating antibodies known as natural antibodies (NAbs) present in blood at early life without any previous immunogenic challenge $(1,2)$. NAbs are spontaneously produced primarily by B-1 cells and their levels, and antigen affinities, remain almost constant during lifetime (3). NAbs (mostly IgM) are encoded by their genes in germline configuration by B cells, which have not been subjected to somatic hypermutation and affinity maturation (4). In fact, at least $80 \%$ of the serum IgM, in healthy conditions, is produced by this way (5). Little is known about factors involved in the regulation of composition of circulating NAbs. Its origin, repertoire, and physiological role are still controversial and an issue of continued debate (6).

The most expanded origin hypothesis suggests that stimulation of B-1 lymphocytes is produced by exposition to microbiota antigens (7). NAbs were highlighted by the discovery in the early twentieth century of the $\mathrm{ABO}$ antigen system in human blood. After that, a large group of NAbs has been described in humans, which include other alloantibodies related to blood group antigens (Rh, Lewis, etc.), 
xenoantibodies, and antibodies that target tumor-associated antigens $(3,8)$. In general, NAbs show a polyreactive binding as they react to similar epitopes on a variety of molecular entities $(9,10)$. The maintenance of immune homeostasis through the defense against foreign invaders and own damaged/apoptotic cells, and the housekeeping removal of cellular debris or metabolite clearance, are functions attributed to NAbs $(10,11)$. Most of these antibodies target carbohydrate structures, and have been reported to play protective, but also pathogenic roles, in both autoimmune and inflammatory diseases $(12,13)$. Therefore, an understanding of the composition and function of the glycanreactive $\mathrm{NAb}$ repertoire in a healthy condition continues being an issue of paramount importance (13).

The Printed Glycan Array (PGA) technology has a high sensitivity and offers the possibility to analyze hundreds of different glycan antigens to explore circulating natural anti-carbohydrate antibodies in different species $(8,9,14,15)$. This allows the minimization of one of the major problems associated with the analysis of anti-carbohydrate antibodies; the cross-reactivity of a particular antibody with different glycans (16). Mice and specifically the BALB/c strain is one of the animal species more often used as a model of human diseases in both cancer and immunology research (17). Although there are previous reports regarding global analysis of the natural antibody repertoire (18-20), little is known about the exact specificities targeted by natural anticarbohydrate antibodies in these animals, and which of them are shared with humans. The study presented by Dai et al. (20) is limited to a reduced number of glycan moieties, including four representative carbohydrate structures: homo-polysaccharides of 1,4-linked-D-galactopyranosyluronic acids, 1,6-glucan (dextran), 1,3 -mannan and $\beta$-glucan. From these glycan structures, mannan was not recognized by serum Abs from any of the mouse and rat strains examined and some variability regarding of glycan recognition among mice strains under examination was reported. Despite this, the authors concluded that IgM reactivity repertoires against glycan antigens in rodents are practically homogeneous within inbred strains and largely conserved in the species.

The present work is aimed to describe the natural anticarbohydrate antibody repertoire of BALB/c mice by PGA, using a library of 419 different fully characterized glycan structures, and to compare their binding specificities with that of human natural anti-carbohydrate antibodies.

\section{MATERIALS AND METHODS}

\section{Ethics Statement}

Animals were handled in strict accordance with good animal practice as defined by the relevant local animal welfare bodies. All animal procedures were supervised and approved by Bellvitge Biomedical Research Institute (IDIBELL) ethics committee for animal experimentation and the Catalonia Government. The care and handling of the animals were conformed to the Guide for the Care and Use of Laboratory Animals published by the US National Institutes of Health (NIH Publication no. 85-23 revised 1996) and the European Agreement on Vertebrate Animal Protection for Experimental Use (86/609).

\section{BALB/c Mice}

BALB/c mice 10-week-old (Harlan, France), 13 female and 7 male, were maintained in separated cages at IDIBELL animal facility (specific pathogen free, SPF) under controlled conditions of temperature $\left(21 \pm 1^{\circ} \mathrm{C}\right)$, humidity (55 $\left.\pm 5 \%\right)$, cycles of light/ dark of $12 / 12 \mathrm{~h}$, and with food and water given ad libitum.

\section{Serum Collection and Processing}

Mice blood extraction was made without the need of anesthesia by submandibular bleeding (21). Serum was collected by mild centrifugation $\left(10 \mathrm{~min}, 1,200 \mathrm{~g}\right.$ at $4^{\circ} \mathrm{C}$ ) and stored at $-80^{\circ} \mathrm{C}$ for further analysis. The human serum was collected from 11 human healthy donors, processed and stored under similar condition by Semiotik LLC.

\section{Glycan Array Analysis}

Glycochips were prepared by Semiotik LLC (Moscow, Russia) from 419 different synthetic amine-functionalized glycans, using $\mathrm{N}$-hydroxysuccinimide-derivatized glass slides (slide $\mathrm{H}$, SchottNexterion, Mainz, Germany), as described in Ref. $(3,15)$. The glycan library included blood group antigens and some of the most frequently occurring terminal oligosaccharides, as well as core motifs of mammalian $\mathrm{N}$ - and $\mathrm{O}$-linked glycoproteins and glycolipids, tumor-associated carbohydrate antigens, and polysaccharides from pathogenic bacteria. Synthetic glycan structures ( $>95 \%$ purity) are structurally the same as natural ones. Structures and NMR data of polysaccharides and related references are in http://csdb.glycoscience.ru/bacterial (Zelinsky Institute of Organic chemistry, Moscow, Russia). All glycans were printed in six replicates. After printing, glycochips were incubated in an incubation chamber for $15 \mathrm{~min}$ at $25^{\circ} \mathrm{C}$ with PBS plus $0.1 \%(\mathrm{v} / \mathrm{v})$ Tween-20 (buffer 3) (Sigma-Aldrich, St. Louis, MO, USA), and the buffer was then carefully removed from the microchip surface using Whatman ${ }^{\circledR}$ filter paper (Sigma-Aldrich, St. Louis, MO, USA). BALB/c mouse sera were diluted (1:15) in PBS plus $1 \%(\mathrm{w} / \mathrm{v})$ bovine serum albumin (BSA; Sigma-Aldrich, St. Louis, MO, USA) and 1\% (v/v) Tween-20 (buffer 1). Diluted serum was spread over the slide surface and incubated with agitation $(30 \mathrm{rpm})$ at $37^{\circ} \mathrm{C}$ for $1.5 \mathrm{~h}$. After a round of washing steps with buffer 3, buffer 4 (PBS with $0.001 \%$ v/v Tween-20), and distilled water (Milli-Q grade), the glycochips were drained by mild centrifugation ( $1 \mathrm{~min}, 175 \mathrm{~g}$, Eppendorf, Hamburg, Germany). The glycochips were then incubated for $1 \mathrm{~h}$ at $37^{\circ} \mathrm{C}$ $(30 \mathrm{rpm})$ with goat anti-mouse $\operatorname{IgG}+\operatorname{IgM}(\mathrm{H}+\mathrm{L})$ conjugated to biotin (Thermo Fisher Scientific, Waltham, MA, USA) and diluted 200-fold in PBS plus 1\% BSA and 0.1\% Tween-20 (buffer 2 ). The unbound fraction was removed by repeating the same round of washing steps. Glass slides were incubated in darkness at $25^{\circ} \mathrm{C}$ for $45 \mathrm{~min}(30 \mathrm{rpm})$ with streptavidin labeled with $\mathrm{Cy} 5$ dye (GE Healthcare, Little Chalfont, Buckinghamshire, UK) and diluted 1:500 in buffer 2. After another round of washing, the glycochips were dried by airflow in darkness. Finally, the glycochips were scanned using a ScanArray GX Plus scanner (PerkinElmer, Waltham, MA, USA) with a laser (excitation wavelength of $633 \mathrm{~nm}$ ). All data analysis was performed with the ScanArray ${ }^{\circledR}$ Express Microarray Analysis System (PerkinElmer, 
Waltham, MA, USA). The binding results were expressed in relative fluorescence units (RFU) as median \pm median absolute deviation (MAD). Interactive exploration of multidimensional data (heat mapping and clustering analysis) was performed with the Hierarchical Clustering Explorer application developed by the University of Maryland, MD, USA. ${ }^{1}$

\section{RESULTS}

To avoid potentially confounding differences in genetic backgrounds, BALB/c mice were taken from inbred SPF populations (Harlan, France). The repertoire of circulating natural anticarbohydrate antibodies was studied by PGA technology using a library of 419 different glycan structures. Although a previous study (22) showed that in normal mouse sera IgM can bind the $\mathrm{F}\left(\mathrm{ab}^{\prime}\right)_{2}$ of natural IgG autoantibodies, thus the dilution of normal serum decreases such IgM anti-IgG autoantibodies and unmasks these natural IgG autoantibodies, we have demonstrated that this dilution dependent effect is not present in our test system (15). Hence, we have used diluted sera (1:15) in all PGA determinations. In the case of mice due to the constraint in the serum amount, IgG and IgM anti-carbohydrate antibodies were simultaneously determined. Structural identity of polysaccharides was confirmed by NMR (deposited in http://csdb.glycoscience.ru/ bacterial). All carbohydrates used in the PGA structurally were the same as natural ones. However, density in the slide, length of spacer or type of carrier (protein or another polymer, peptide, etc.) can influence their activity. Therefore, their presentation on the array is quite possibly far from natural presentation $(23,24)$. Nevertheless, this constraint of our in vitro approach had no impact on the main objective of our work because both sets of PGA determinations (humans and mice) were carried out using the same glycan library and conditions; hence, were similarly affected.

The data resulting from PGA experiments have been deposited in NCBI GEO Database (25) with the name "Repertoire of $\mathrm{BALB} / \mathrm{c}$ mice natural anti-carbohydrate antibodies," and are accessible through GEO Series accession number GSE97151. ${ }^{2}$

In the PGA, we considered values above $4,000 \mathrm{RFU}$ as a positive signal of antibody binding (this value is $\sim 10 \%$ of the top glycans RFU), which were expressed as the median \pm median absolute deviation (MAD) (Table S1 in Supplementary Material). The majority of printed glycans were not targeted by any natural antibody present in the serum of BALB/c mice (Figure 1, in blue), and 71 carbohydrates (Figure 1, in red) demonstrated $\geq 4,000$ RFU in the PGA (see NCBI GEO Database: GSE97151). The top rank glycans included 12 with median signal intensities of bound antibodies $\geq 10,000$ RFU (Table 1). Seven of them were recognized by serum antibodies from all the mice involved in the study, while other five glycans were targeted by serum samples of at least $80 \%$ of animals (Table 1). Sulfated glycans comprised $50 \%$ of the high-binding glycans and $\beta \mathrm{Gal}$-terminated oligosaccharides $25 \%$. About gender, we did not observe marked differences between male and female in the majority of top rank glycans listed in Table $\mathbf{1 .}$

Most of the circulating anti-glycan antibodies found in mice were not widely represented in the human sera, as the number of human donors showing signals $\geq 4,000$ RFU in the PGA was limited or absent for the major part of these top rank glycan structures (Table 1). Concomitantly, the high level circulating anti-glycan antibodies found in humans (Table 2) were poorly

${ }^{1}$ http://www.cs.umd.edu/hcil/hce/.

${ }^{2}$ https://www.ncbi.nlm.nih.gov/geo/query/acc.cgi?acc=GSE97151.

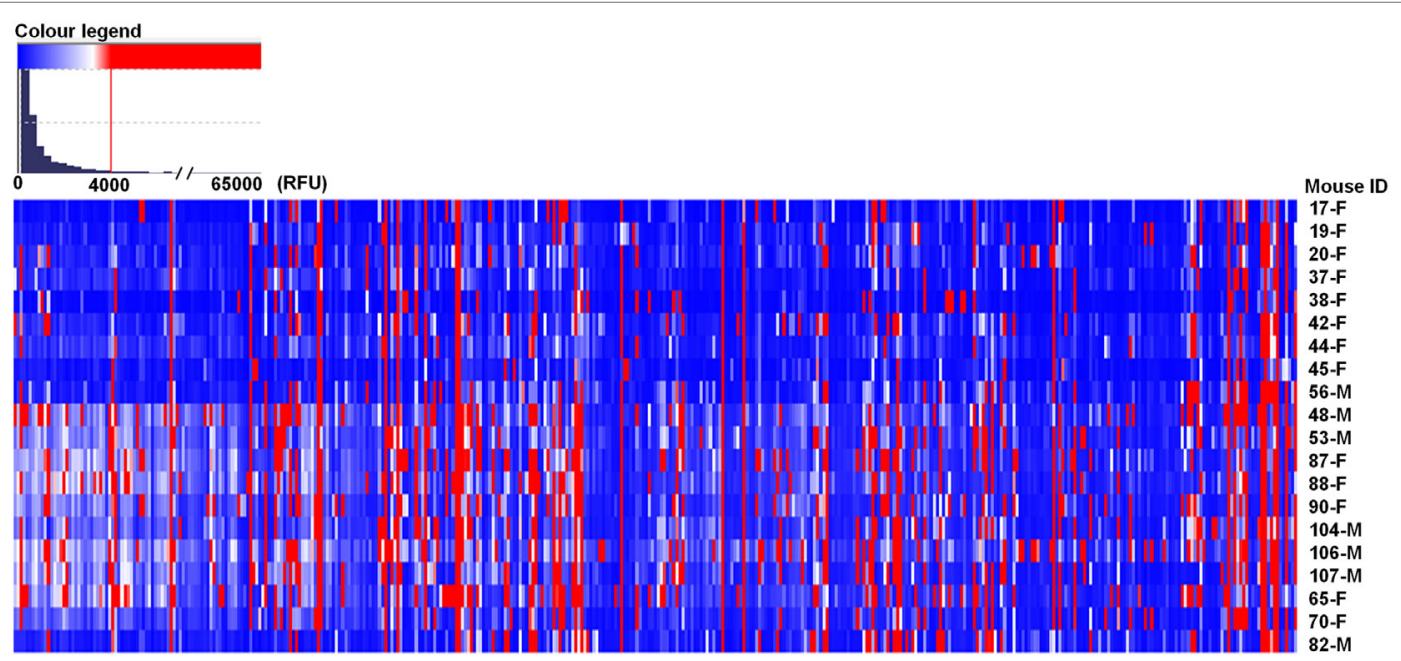

FIGURE 1 | BALB/c mice showed different repertoire of natural circulating anti-carbohydrate antibodies. Mouse ( $n=20)$ serum (1:15) was incubated with chips printed with 419 glycans. Chips were scanned using a ScanArray GX Plus reader and data were analyzed with the ScanArray ${ }^{\circledR}$ Express Microarray Analysis System (PerkinElmer). The binding results for lgM + IgG were expressed in relative fluorescence units (RFU) as median \pm median absolute deviation (MAD). In the heat map, blue and white colors represent binding signals, in RFU, lower than 4,000 (background); red color signals $\geq 4,000$ RFU (positive binding). F, female; M, male. 
TABLE 1 | Specificity of carbohydrates targeting natural antibodies in BALB/c mice.

\begin{tabular}{|c|c|c|c|c|c|c|c|}
\hline \multirow[t]{2}{*}{ Glycan ID (\#) } & \multirow[t]{2}{*}{ Structure } & \multirow[t]{2}{*}{ Common name } & \multicolumn{2}{|c|}{$\begin{array}{l}\text { Median and } \\
\text { MAD as RFU }\end{array}$} & \multirow[t]{2}{*}{$\begin{array}{l}\text { Number of mice showing } \\
\text { RFU } \geq \mathbf{4 , 0 0 0}(\%)\end{array}$} & \multicolumn{2}{|c|}{$\begin{array}{l}\text { Number of human donors } \\
\text { showing RFU } \geq 4,000 \text { (\%) }\end{array}$} \\
\hline & & & & & & $\lg M$ & $\lg G$ \\
\hline 060 & 6-O-Su-Gal $\beta$-sp ${ }^{\mathrm{a}}$ & & 61,113 & 1,156 & 100 & 73 & 0 \\
\hline 271 & Gal $\beta 1-6 \mathrm{Gal} \beta 1-4 \mathrm{Glc} \beta-\mathrm{sp}$ & & 53,622 & 1,934 & 100 & 55 & 27 \\
\hline 802 & Gal $\beta 1-3$ GalNAc(fur) $\beta$-sp & & 51,348 & 2,324 & 100 & 73 & 9 \\
\hline 176 & 3-O-Su-Gal $\beta 1-4(6-O-S u) G l c \beta-s p$ & & 43,008 & 9,342 & 100 & 9 & 0 \\
\hline 166 & GlcA $\beta 1-6 \mathrm{Gal} \beta-\mathrm{sp}$ & & 39,105 & 2,993 & 85 & 18 & 0 \\
\hline 150 & 3-O-Su-Gal $\beta 1-3 G a l N A c \alpha-s p$ & & 37,943 & 3,232 & 100 & 18 & 0 \\
\hline 437 & GalNAc $\alpha 1-3($ Fuc $\alpha 1-2)$ Gal $\beta 1-3$ GalNAc $\beta-s p$ & A(type 4) & 33,886 & 3,193 & 90 & 45 & 45 \\
\hline 125 & 6-Bn-Gal $\beta 1-4 \mathrm{GlcNAc} \beta-\mathrm{sp}$ & & 32,674 & 5,389 & 95 & 0 & 0 \\
\hline 154 & 3-O-Su-Gal $\beta 1-3 G \mid c N A c \beta-s p$ & & 32,651 & 3,954 & 100 & 64 & 36 \\
\hline 177 & 3-O-Su-Galß1-4(6-O-Su)GlcNAc $\beta$-sp & & 32,496 & 7,215 & 100 & 9 & 9 \\
\hline 287 & 3-O-Su-Gal $\beta 1-3(F u c \alpha 1-4)$ GlcNAc $\beta$-sp & SuLe ${ }^{a}$ & 20,063 & 4,962 & 95 & 0 & 9 \\
\hline 234 & Gal $\beta 1-4(F u c \alpha 1-3)$ GlcNAc $\beta$-sp & $\operatorname{Le}^{x}$ & 13,573 & 2,635 & 80 & 0 & 0 \\
\hline
\end{tabular}

List of glycans with binding signals above 4,000 relative fluorescence units (RFU) in at least $80 \%$ of examined mice $(n=20)$. Comparison with human data ( $n=11)$. The data obtained by Semiotik LLC, Russia, in the same conditions.

${ }^{a} s p$ means aminoethyl, aminoprolyl, or glycyl spacer.

TABLE 2 | Specificity of carbohydrates targeting natural antibodies in humans.

\begin{tabular}{|c|c|c|c|c|c|}
\hline \multirow[t]{2}{*}{ Glycan ID (\#) } & \multirow[t]{2}{*}{ Structure } & \multirow[t]{2}{*}{ Common name } & \multicolumn{2}{|c|}{$\begin{array}{l}\text { Number of human donors showing } \\
\qquad \text { RFU } \geq 4,000(\%)\end{array}$} & \multirow[t]{2}{*}{$\begin{array}{l}\text { Number of mice showing } \\
\text { RFU } \geq 4,000(\%)\end{array}$} \\
\hline & & & $\lg M$ & $\lg G$ & \\
\hline 019 & ManNAc $\beta-\mathrm{sp}^{\mathrm{a}}$ & & 91 & 91 & 20 \\
\hline 080 & Gal $\alpha 1-3 G \mid c N A c \beta-s p$ & & 82 & 82 & 0 \\
\hline 082 & Gal $\alpha 1-4$ GlcNAc $\beta-s p$ & $\alpha\llcorner N$ & 73 & 73 & 5 \\
\hline 101 & GalNAc $\alpha 1-3$ GalNAc $\beta$-sp & Fs-2 & 82 & 91 & 5 \\
\hline 149 & GlcNAc $\beta 1-4(6-O-S u)$ GlcNAc $\beta-s p$ & & 82 & 82 & 25 \\
\hline 246 & GlcNAc $\beta 1-2$ Gal $\beta 1-3 G a l N A c \alpha-s p$ & & 91 & 82 & 0 \\
\hline 256 & GlcNAc $\beta 1-6(G \mid c N A c \beta 1-4)$ GalNAc $\alpha-s p$ & & 91 & 91 & 40 \\
\hline 278 & GalNAc $\alpha 1-3$ GalNAc $\beta 1-3 G a l \beta-s p$ & Fs-3 & 73 & 82 & n.d \\
\hline 375 & Gal $\alpha 1-4 \mathrm{GlcNAc} \beta 1-3 \mathrm{Gal} \beta 1-4 \mathrm{GlcNAc} \beta-\mathrm{sp}$ & & 73 & 73 & 5 \\
\hline 378 & Gal $\beta 1-3 G|c N A c \alpha 1-3 G a l \beta 1-4 G| c N A c \beta-s p$ & & 82 & 73 & 45 \\
\hline 399 & Gal $\beta 1-3 G|c N A c \alpha 1-3 G a l \beta 1-3 G| c N A c \beta-s p$ & & 82 & 82 & 50 \\
\hline 806 & Gal $\alpha 1-6 \mathrm{Gl} \alpha \alpha-\mathrm{sp}$ & & 82 & 73 & 20 \\
\hline 808 & Gal $\alpha 1-6 \mathrm{Gl} / \beta-\mathrm{sp}$ & Melibiose & 91 & 73 & 35 \\
\hline
\end{tabular}

List of glycans with binding signals above 4,000 relative fluorescence units (RFU) for both, IgM and lgG antibodies in at least $70 \%$ of human donors ( $n=11$ ). Comparison with mice data $(n=20)$. The data obtained by Semiotik LLC, Russia, in the same conditions.

${ }^{a}$ sp means aminoethyl, aminoprolyl, or glycyl spacer.

n.d, not determined.

represented among the animals assessed. Additionally, humans showed, like mice, significant variability between individuals in the level and diversity of circulating anti-glycan antibodies (Figure 2; Table S2 in Supplementary Material).

\section{DISCUSSION}

Murine and specifically BALB/c mice are among the most widely used inbred strains for animal experimentation to address almost every aspect of human health (17). This work demonstrates that genetically identical SPF mice should not be considered as "totally equivalents" from the immunological view as they present, despite some conservatism, different patterns of natural circulating anti-carbohydrate antibodies, which also differ dramatically from the conserved anti-carbohydrate antibody repertoire found in humans. Previous global analysis of natural antibody repertoires has revealed a marked conservation of reactivity patterns within inbred mouse strains (18-20). However, some of these studies must be analyzed with caution due to the limited number of glycans assessed (20). This homogeneity among genetically identical animals was not observed in our study (25), and could be explained by the differences demonstrated in the analysis of the gut microbial population of inbred animals (26). If the production of natural anti-carbohydrate antibodies is triggered by the antigenic stimulation of microbiota, and this is different among inbred mice, fine specificity of these antibodies will not be identical.

There are also significant differences between mice and humans regarding the primary glycan specificities targeted by natural anticarbohydrate antibodies. The discrepancy in repertoires is quite evident if top rank carbohydrates recognized by mice antibodies 


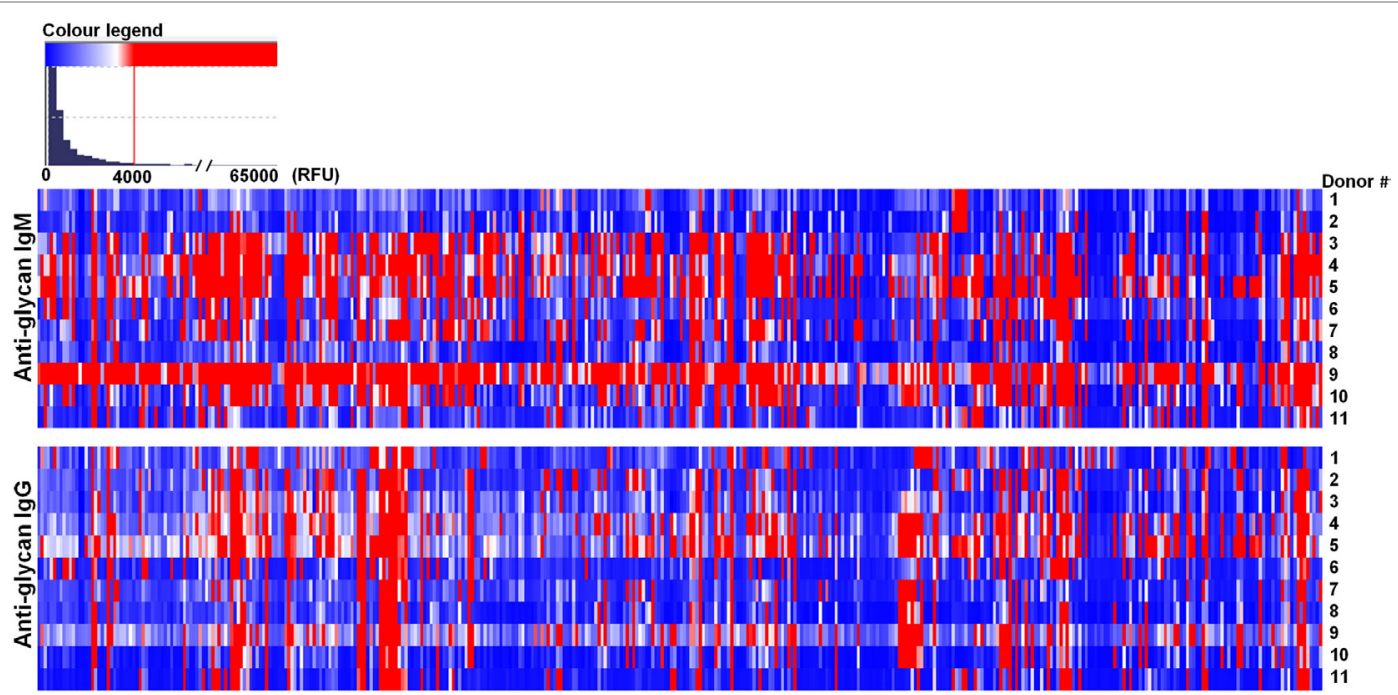

FIGURE 2 | Humans showed different repertoire of natural circulating anti-carbohydrate antibodies. Human $(n=11)$ serum (1:15) was incubated with chips printed with 419 glycans. Chips were scanned using a ScanArray GX Plus reader and data were analyzed with the ScanArray ${ }^{\circledR}$ Express Microarray Analysis System (PerkinElmer). The binding results for IgM and IgG were expressed in relative fluorescence units (RFU) as median \pm median absolute deviation (MAD). In the heat map blue and white colors represent binding signals, in RFU, lower than 4,000 (background); red color signals $\geq 4,000$ RFU (positive binding).

are directly compared with the top rank of circulating anti-glycan antibodies in humans (3). This disparity cannot be attributed to alloantibodies because in humans anti-blood group antibodies (like anti-A, anti-B, anti-Lewis) are not top rank immunoglobulins (3). The most intriguing appear to be the rather high level of anti-Le ${ }^{\mathrm{X}}$ in $\mathrm{BALB} / \mathrm{c}$ mice. In humans, healthy donors never have antibodies to Le ${ }^{\mathrm{X}}$ epitope, Gal $\beta 1-4($ Fuc $\alpha 1-3)$ GlcNAc $\beta$, as well as to related so-called type 2 motif containing antigens (i.e., structures with Gal $\beta 1-4 G l c N A c$ core) like $\mathrm{Le}^{\mathrm{Y}}$ and SiaLe ${ }^{\mathrm{X}}$. The absence of these antibodies in humans is easy to explain: $\mathrm{Le}^{\mathrm{X}}$ termination is known as the structure of many glycoproteins and glycolipids of endothelial and blood group cells membrane. In contrast to humans, $80 \%$ of BALB/c mice demonstrated moderate levels of anti-Le ${ }^{\mathrm{X}}$ antibodies. The "moderate" means a level comparable or higher than, for example, titers of anti-A/B alloantibodies, or anti- $\alpha$ Gal xenoantibodies, which cause hemolytic reactions or organ rejection in humans. In mice, $\mathrm{Le}^{\mathrm{X}}$ is known as stage-specific embryonic antigen-III and plays a crucial role in neurogenesis, embryogenesis, and reproduction system $(27,28)$. Why in $\mathrm{BALB} / \mathrm{c}$ mice the antibodies coexist with cognate antigen without immunologic attack remains unclear. Notably, other mice strains (29) also found to have anti-Le ${ }^{\mathrm{X}}$ NAbs, with an apparent function to protect from Schistosoma parasites (30). Concurrently, top anti-glycan antibodies conserved among humans $(3,8)$, such as GlcNAc $\beta$-terminated, GlcNAc $\alpha$-terminated, Rha, Le ${ }^{\mathrm{C}}, \mathrm{Fs} / \mathrm{A}_{\mathrm{di}}$, asialo-GM1, and Fuc $\alpha 1-3(4)$ GlcNAc, are completely missing in mice, or, like in case of anti-blood group $\mathrm{P}_{1}$ and $\mathrm{P}^{\mathrm{k}}$ trisaccharides, at very low level. Although we show with the glycan array that $\mathrm{BALB} / \mathrm{c}$ and human IgM have different glycan binding specificities, these differences may not significantly alter the functional effect of human or mouse IgM on murine cells as shown in prior studies $(31-33)$.
The differences observed in the repertoire of anti-carbohydrate antibodies in genetically identical BALB/c mice, and between these mice and humans, also reflect the uncertainties about the functional role and origin of NAbs. Three hypotheses attempt to explain the development of these antibodies (6). The first suggests the specific stimulation by new antigens of the bacterial microbiota; the second is based on the response to endogenous degradation products of normal cells, not to neoantigens; and the third proposes that NAbs result from the exposure to molecular patterns. The latter are different conserved molecules located close to each other that can be divided into two groups: MAMPs, microorganism associated molecular patterns, composed of polysaccharides, and DAMPs, damage associated molecular patterns, constituted by proteins. In the case of polysaccharides, human anti-glycan antibodies, including anti-A/B allo-agglutinins, antibodies to glycoprotein $O$-chain glycans Gal $\beta 1-3 \mathrm{GalNAc} \alpha$ (TF) and GalNAc $\alpha(\mathrm{Tn})$, are risen due to contact of the newborn immune system with intestinal microbiota $(34,35)$. Pivotal role in this phenomenon might play bacterial polysaccharides, structure of which mimics ABH blood groups $(7,36), \mathrm{TF} / \mathrm{Tn}$ or other related mammalian glycans $(37,38)$. From the moment of birth, the gastrointestinal tract and respiratory system in mammals are actively colonized by bacteria. About 103 species of non-pathogenic (commensal) bacteria form the basis of normal intestinal microbiota (39), although the total number of species is estimated to be greater. These bacteria possess millions of antigens, and they are capable to prime those B-1 lymphocytes which are genetically selected for the synthesis of NAbs $(6,40)$. It was shown that up to $90 \%$ of the immunoglobulin-secreting cells of the normal mouse intestine produce natural Abs that are absent in germ-free mice $(41,42)$. Thus, the appearance of a particular natural anti-carbohydrate antibody requires "two 
keys" - the existence of B-1 cell gene and the priming with bacterial antigen (a mimotope of the cognate antigen). Bacteria are the best source for anti-carbohydrate antibody priming for two additional reasons: (1) appearance only after birth, (2) the need of toll-like receptors for recognition by B-1 cells; this mechanism excludes priming of B-1 cells with auto-antigens at the embryonic stage (6). Genetics of B-cells, as well as microbiotas of humans and mice are different, so it is not surprising that the resulting repertoires of NAbs are not similar. At the same time, since some of the NAbs (for instance, anti-A/B) play a similar physiologically active role, they are similar in different species.

In summary, the results presented here indicate that the repertoires of circulating natural anti-glycan antibodies in BALB/c mice appear to be not identical for genetically identical individual animals. Additionally, mice antibody repertoire shows significant differences to that present in humans, suggesting a caution when using mice as an animal model for investigation of human NAbs for biomedical studies.

\section{ETHICS STATEMENT}

Animals were handled in strict accordance with good animal practice as defined by the relevant local animal welfare bodies. All animal procedures were supervised and approved by Bellvitge Biomedical Research Institute (IDIBELL) ethics committee for animal experimentation and the Catalonia Government. The care and handling of the animals were conformed to the Guide for the Care and Use of Laboratory Animals published by the US National Institutes of Health (NIH Publication no. 85-23

\section{REFERENCES}

1. Baumgarth $\mathrm{N}$. The double life of a B-1 cell: self-reactivity selects for protective effector functions. Nat Rev Immunol (2011) 11(1):34-46. doi:10.1038/ nri2901

2. Savage HP, Baumgarth N. Characteristics of natural antibody-secreting cells. Ann N Y Acad Sci (2015) 1362:132-42. doi:10.1111/nyas.12799

3. Huflejt ME, Vuskovic M, Vasiliu D, Xu H, Obukhova P, Shilova N, et al. Anticarbohydrate antibodies of normal sera: findings, surprises and challenges. Mol Immunol (2009) 46(15):3037-49. doi:10.1016/j.molimm.2009.06.010

4. Coutinho A, Kazatchkine MD, Avrameas S. Natural autoantibodies. Curr Opin Immunol (1995) 7:812-8. doi:10.1016/0952-7915(95)80053-0

5. Bovin N. Natural antibodies to glycans. Biochemistry (Mosc) (2013) 78(7):786-97. doi:10.1134/S0006297913070109

6. Khasbiullina NR, Bovin NV. Hypotheses of the origin of natural antibodies: a glycobiologist's opinion. Biochemistry (Mosc) (2015) 80(7):820-35. doi:10.1134/ S0006297915070032

7. Springer GF, Horton RE. Blood group isoantibody stimulation in man by feeding blood group-active bacteria. J Clin Invest (1969) 48:1280-91. doi:10.1172/ JCI106094

8. Bovin N, Obukhova P, Shilova N, Rapoport E, Popova I, Navakouski M, et al. Repertoire of human natural anti-glycan immunoglobulins. Do we have auto-antibodies? Biochim Biophys Acta (2012) 1820(9):1373-82. doi:10.1016/j. bbagen.2012.02.005

9. de los Rios M, Criscitiello MF, Smider VV. Structural and genetic diversity in antibody repertoires from diverse species. Curr Opin Struct Biol (2015) 33:27-41. doi:10.1016/j.sbi.2015.06.002

10. Gunti S, Notkins AL. Polyreactive antibodies: function and quantification. J Infect Dis (2015) 212(Suppl 1):S42-6. doi:10.1093/infdis/jiu512 revised 1996) and the European Agreement of Vertebrate Animal Protection for Experimental Use (86/609).

\section{AUTHOR CONTRIBUTIONS}

Contributions of the authors can be summarized as follows: performed the experiments: DB-G and NK. Analyzed the data: DB-G, NK, NS, NB, and RM. Contributed reagents/materials/ analysis tools: NB and RM. Wrote the article: DB-G. Contributed with ideas: DB-G, NK, NS, NB, and RM.

\section{ACKNOWLEDGMENTS}

This work was supported by "Fondo de Investigaciones Sanitarias" (FIS) grant PI13/01098 from Carlos III Health Institute, Spanish Ministry of Health. DB-G was benefited of a post-doctoral research position funded by the European Union Seventh Framework Programme (FP7/2007-2013) under the Grant Agreement 603049 (TRANSLINK). Work of NK, NS, and NB was supported by grant \#14-50-00131 of Russian Science Foundation. None of the sponsors were directly involved in the study. DB-G wants to express his gratitude to Laia Muxi, Marta Broto, and J. Pablo Salvador for excellent technical assistance, and Alexander Rakitko for assistance in statistical analysis.

\section{SUPPLEMENTARY MATERIAL}

The Supplementary Material for this article can be found online at http://www.frontiersin.org/article/10.3389/fimmu.2017.01449/ full\#supplementary-material.

11. Vas J, Grönwall C, Silverman GJ. Fundamental roles of the innate-like repertoire of natural antibodies in immune homeostasis. Front Immunol (2013) 4:4 doi:10.3389/fimmu.2013.00004

12. Kearney JF, Patel P, Stefanov EK, King RG. Natural antibody repertoires: development and functional role in inhibiting allergic airway disease. Annu Rev Immunol (2015) 33:475-504. doi:10.1146/annurev-immunol-032713120140

13. New JS, King RG, Kearney JF. Manipulation of the glycan-specific natural antibody repertoire for immunotherapy. Immunol Rev (2016) 270(1):32-50. doi:10.1111/imr.12397

14. Pochechueva T, Jacob F, Goldstein DR, Huflejt ME, Chinarev A, Caduff R, et al. Comparison of printed glycan array, suspension array and ELISA in the detection of human anti-glycan antibodies. Glycoconj J (2011) 28(8-9):507-17. doi:10.1007/s10719-011-9349-y

15. Shilova N, Navakouski M, Khasbiullina N, Blixt O, Bovin N. Printed glycan array: antibodies as probed in undiluted serum and effects of dilution. Glycoconj J (2012) 29(2-3):87-91. doi:10.1007/s10719-011-9368-8

16. Manimala JC, Roach TA, Li Z, Gildersleeve JC. High-throughput carbohydrate microarray profiling of 27 antibodies demonstrates widespread specificity problems. Glycobiology (2007) 17:17C-23C. doi:10.1093/glycob/cwm047

17. Ormandy EH, Schuppli CA, Weary DM. Worldwide trends in the use of animals in research: the contribution of genetically-modified animal models. Altern Lab Anim (2009) 37(1):63-8.

18. Bos NA, Meeuwsen CG, Van Wijngaarden P, Benner R. B cell repertoire in adult antigen-free and conventional neonatal BALB/c mice. II. Analysis of antigen-binding capacities in relation to VH gene usage. Eur J Immunol (1989) 19(10):1817-22. doi:10.1002/eji.1830191009

19. Vasconcellos R, Nobrega A, Haury M, Viale AC, Coutinho A. Genetic control of natural antibody repertoires: I. IgH, MHC and TCR beta loci. 
Eur J Immunol (1998) 28(3):1104-15. doi:10.1002/(SICI)1521-4141(199803) 28:03<1104::AID-IMMU1104>3.0.CO;2-O

20. Dai H, Zhang Y, Lv P, Gao XM. A study on the glycan specificity of natural antibody repertoires in rodents. Cell Mol Immunol (2009) 6(6):453-9. doi:10.1038/cmi.2009.57

21. Golde WT, Gollobin P, Rodriguez LL. A rapid, simple, and humane method for submandibular bleeding of mice using a lancet. Lab Anim (NY) (2005) 34(9):39-43. doi:10.1038/laban1005-39

22. Adib M, Ragimbeau J, Avrameas S, Ternynck T. IgG autoantibody activity in normal mouse serum is controlled by IgM. J Immunol (1990) 145(11):3807-13.

23. Grant OC, Smith HM, Firsova D, Fadda E, Woods RJ. Presentation, presentation, presentation! Molecular-level insight into linker effects on glycan array screening data. Glycobiology (2014) 24(1):17-25. doi:10.1093/glycob/cwt083

24. Song X, Heimburg-Molinaro J, Cummings RD, Smith DF. Chemistry of natural glycan microarrays. Curr Opin Chem Biol (2014) 18:70-7. doi:10.1016/j. cbpa.2014.01.001

25. Bello-Gil D, Mañez R. Data from: Repertoire of BALB/c Mice Natural AntiCarbohydrate Antibodies. NCBI GEO Database, GSE97151. (2017). Available from: https://www.ncbi.nlm.nih.gov/geo/query/acc.cgi?acc=GSE97151

26. Hoy YE, Bik EM, Lawley TD, Holmes SP, Monack DM, Theriot JA, et al. Variation in taxonomic composition of the fecal microbiota in an inbred mouse strain across individuals and time. PLoS One (2015) 10(11):e0142825. doi:10.1371/journal.pone.0142825

27. Rosenman SJ, Fenderson BA, Hakomori SI. Murine embryonal carcinoma cell-surface sialyl LeX is present on a novel glycoprotein and on high-molecular-weight lactosaminoglycan. Exp Cell Res (1989) 180:326-40. doi:10.1016/0014-4827(89)90061-X

28. Wang C, Huang C, Gu Y, Zhou Y, Zhu Z, Zhang Y. Biosynthesis and distribution of Lewis X-and Lewis Y-containing glycoproteins in the murine male reproductive system. Glycobiology (2011) 21:225-34. doi:10.1093/glycob/ cwq152

29. Umeda M, Diego I, Marcus DM. The occurrence of anti-3-fucosyllactosamine antibodies and their cross-reactive idiotopes in preimmune and immune mouse sera. J Immunol (1986) 137(10):3264-9.

30. Richter D, Incani RN, Harn DA. Lacto-N-fucopentaose III (Lewis $\mathrm{x}$ ), a target of the antibody response in mice vaccinated with irradiated cercariae of Schistosoma mansoni. Infect Immun (1996) 64(5):1826-31.

31. Robey IF, Schluter SF, Akporiaye E, Yocum DE, Marchalonis JJ. Human monoclonal natural autoantibodies against the T-cell receptor inhibit interleukin-2 production in murine T cells. Immunology (2002) 105(4):419-29. doi:10.1046/j.1365-2567.2002.01389.x

32. Zhang M, Alicot EM, Carroll MC. Human natural IgM can induce ischemia/ reperfusion injury in a murine intestinal model. Mol Immunol (2008) 45(15):4036-9. doi:10.1016/j.molimm.2008.06.013

33. Lobo PI, Schlegel KH, Bajwa A, Huang L, Kurmaeva E, Wang B, et al. Natural IgM switches the function of lipopolysaccharide-activated murine bone marrow-derived dendritic dells to a regulatory dendritic cell that suppresses innate inflammation. JImmunol (2015) 195(11):5215-26. doi:10.4049/ jimmunol.1500052

34. Springer GF, Horton RE, Forbes M. Origin of antihuman blood group B agglutinins in germfree chicks. Ann N Y Acad Sci (1959) 78:272-5. doi:10.1111/ j.1749-6632.1959.tb53110.x

35. Springer GF. Blood-group and Forssman antigenic determinants shared between microbes and mammalian cells. Prog Allergy (1971) 15:9-77. doi:10.1159/000313046

36. Stowell SR, Arthur CM, Dias-Baruffi M, Rodrigues LC, Gourdine JP, Heimburg-Molinaro J, et al. Innate immune lectins kill bacteria expressing blood group antigen. Nat Med (2010) 16(3):295-301. doi:10.1038/nm.2103

37. Klaamas K, Kurtenkov O, Rittenhouse-Olson K, Brjalin V, Miljukhina L, Shljapnikova L, et al. Expression of tumor-associated Thomsen-Friedenreich antigen ( $\mathrm{T} \mathrm{Ag}$ ) in Helicobacter pylori and modulation of $\mathrm{T} \mathrm{Ag}$ specific immune response in infected individuals. Immunol Invest (2002) 31(3-4):191-204. doi:10.1081/IMM-120016240

38. Henderson G, Ulsemer P, Schöber U, Löffler A, Alpert CA, ZimmermannKordmann M, et al. Occurrence of the human tumor-specific antigen structure Gal 1 1-3GalNAco- (Thomsen-Friedenreich) and related structures on gut bacteria: prevalence, immunochemical analysis and structural confirmation. Glycobiology (2011) 21(10):1277-89. doi:10.1093/glycob/cwr058

39. D'Argenio V, Salvatore F. The role of the gut microbiome in the healthy adult status. Clin Chim Acta (2015) 451(Pt A):97-102. doi:10.1016/j.cca.2015.01.003

40. Butler JE, Sun J, Weber P, Navarro P, Francis D. Antibody repertoire development in fetal and newborn piglets, III. Colonization of the gastrointestinal tract selectively diversifies the preimmune repertoire in mucosal lymphoid tissues. Immunology (2000) 100(1):119-30. doi:10.1046/j.1365-2567.2000.00013.x

41. BosNA,KimuraH,Meeuwsen CG,DeVisserH,Hazenberg MP, Wostmannn BS, et al. Serum immunoglobulin levels and naturally occurring antibodies against carbohydrate antigens in germ-free BALB/c mice fed chemically defined ultrafiltered diet. Eur J Immunol (1980) 19(12):2335-9. doi:10.1002/ eji.1830191223

42. van der Heijden PJ, Bianchi AT, Heidt PJ, Stok W, Bokhout BA. Background (spontaneous) immunoglobulin production in the murine small intestine before and after weaning. JReprod Immunol (1989) 15(3):217-27. doi:10.1016/0165-0378(89)90013-2

Conflict of Interest Statement: The authors declare that the research was conducted in the absence of any commercial or financial relationships that could be construed as a potential conflict of interest.

Copyright $\odot 2017$ Bello-Gil, Khasbiullina, Shilova, Bovin and Mañez. This is an open-access article distributed under the terms of the Creative Commons Attribution License (CC BY). The use, distribution or reproduction in other forums is permitted, provided the original author(s) or licensor are credited and that the original publication in this journal is cited, in accordance with accepted academic practice. No use, distribution or reproduction is permitted which does not comply with these terms. 